\title{
Studies on the Metabolism of the Protozoa
}

\section{METABOLISM OF THE PARASITIC FLAGELLATE STRIGOMONAS ONCOPELTI*}

\author{
BY J. F. RYLEY \\ Imperial Chemical (Pharmaceuticals) Limited, Biological Laboratories, Morley, Wilmslow, Cheshire
}

(Received 12 August 1954)

Strigomonas oncopelti is a flagellate of the family Trypanosomidae parasitic in the latex of the common milkweed, being transmitted from plant to plant by the bite of hemipterous insects. Several strains of the parasite were isolated in bacteria-free culture by Noguchi \& Tilden in 1926. Since then, the organism has been used in a number of nutritional studies concerned with the ability of flagellates to synthesize haematin and thiamine (see M. Lwoff, 1951). A. Lwoff (1934) in a study of the role of haematin in the growth and metabolism of three parasitic flagellates found that about $90 \%$ of the respiration of $S$. oncopelti could be inhibited by cyanide, while a similar parasite Strigomonas fasciculata isolated from the gut of the mosquito Culex pipiens, showed a respiration sensitive to cyanide and carbon monoxide, and contained cytochromes $b$ and/or $c$.

The present study shows that in its catabolic metabolism, $S$. oncopelti bears a striking resemblance to Trypanosoma lewisi (Ryley, 1951). The overall degradation of glucose under both aerobic and anaerobic conditions has been investigated, and the presence of a number of phosphorylating enzyme systems has been demonstrated in cell-free preparations. The flagellate has been found to contain a well-developed cytochrome system, although it seems that some of the respiration is mediated by alternative pathways.

\section{MATERIAL AND METHODS}

Organism. The culture of Strigomonas oncopelti was kindly supplied by Dr J. Colas Belcour of the Institut Pasteur, Paris; it was the no. 4 strain, originally isolated by Noguchi and Tilden from the latex of Asclepias syriaca (M. Lwoff, 1940). The flagellates were cultivated in a sterile medium containing $2 \%(\mathrm{w} / \mathrm{v})$ ' Oxoid' brand Bacteriological peptone (Oxo Ltd.), $0.6 \%(\mathrm{w} / \mathrm{v}) \mathrm{NaCl}$ and $0.8 \%(\mathrm{w} / \mathrm{v})$ glucose, $\mathrm{pH} 7 \cdot 0$; incubation was carried out at $24^{\circ}$. Stock cultures were transfered every week, using two drops of culture/tube as inoculum. A second culture line was maintained in a medium devoid of glucose; in this case the flagellates grew, but cultures were not as heavy as in the presence of glucose. Large-scale cultures were grown in 21. flasks containing 1.5 l. medium. They were harvested using a centrifuge after 4-6 days' growth, and washed and suspended in a Ringer-phosphate solution containing $0.097 \mathrm{M}$ -

* Part 3, Ryley (1952).
$\mathrm{NaCl}, 0.006 \mathrm{M}-\mathrm{KCl}, 0.002 \mathrm{M}-\mathrm{MgSO}_{4}$ and $0.025 \mathrm{~m}$ phosphate buffer $(\mathrm{pH} \mathrm{7 \cdot 3)}$ or a Ringer-bicarbonate solution containing $0.097 \mathrm{M}-\mathrm{NaCl}, 0.006 \mathrm{M}-\mathrm{KCl}, 0.002 \mathrm{M}-\mathrm{MgSO}_{4}$ and $0.016 \mathrm{M}-$ $\mathrm{NaHCO}_{3}$, which when used in conjunction with gas phases containing $5 \% \mathrm{CO}_{2}(\mathrm{v} / \mathrm{v})$, had a $\mathrm{pH}$ of 7.3. Cell-free preparations (homogenates) were made by washing the organisms once in distilled water, and then shaking a thick aqueous suspension of cells with grade 11 Ballotini glass beads for $5 \mathrm{~min}$. in a Mickle disintegrator.

Materials. Cozymase was prepared from baker's yeast to the $30 \%$ purity stage, as described by LePage (1949). Adenosine triphosphate (ATP) was prepared from rabbit muscle as the Ba salt (98-99\% pure) by the method of LePage (1945), using two precipitations with Lohmann's reagent, and converted into the $\mathrm{Na}$ salt before use. Cytochrome $c$ was prepared from ox heart by the method of Keilin \& Hartree (1937) as a $2.15 \times 10^{-4} \mathrm{M}$ solution in $0.9 \%(\mathrm{w} / \mathrm{v}) \mathrm{NaCl}$. Ca fructose 1:6-diphosphate and $K$ glucose 1-phosphate were obtained from L. Light and Co. Ltd.

Spectroscopic observations. These were made using a hand spectroscope (Browning, London) illuminated by a lens system and a pointolite lamp, or a Beck Hartridge reversion spectroscope. The hand spectroscope, although of the prism type, was fitted with a linear scale; this was roughly calibrated with cytochrome $c$ and cells having known absorption bands. The more prominent bands of the spectrum were also observed with the reversion spectroscope, which gives wavelength readings direct. Observations were made both at room temperature and after cooling a cell suspension in $50 \%(v / v)$ aqueous glycerol with liquid nitrogen (Keilin \& Hartree, 1949, 1950).

Metabolic experiments. These were carried out at $30^{\circ}$ in Warburg manometers using cups (vol. 20-25 ml.) fitted with two side arms. Gas phases of air or $5 \% \mathrm{CO}_{2}-95 \% \mathrm{~N}_{2}$ $(v / v)$ were used. Respiratory quotients were measured by the second method of Dickens \& Simer (Dixon, 1934), using a Ringer-bicarbonate solution in conjunction with a gas phase of air containing $5 \%(\nabla / v) \mathrm{CO}_{2}$. Metabolic rates were based on dry weight determinations, being expressed as $Q_{\mathrm{O}_{2}}$ or $Q_{\mathrm{Co}}^{\mathrm{N}}$, i.e. as $\mu$ l. gas/mg. dry weight/hr., or on the $\mathrm{N}$ content of the suspension, being expressed as $q_{\mathrm{O}_{2}}$ or $q_{\mathrm{CO}_{2}}^{\mathrm{N}}$, i.e. as $\mu$ l. gas $/ \mathrm{mg}$. $\mathrm{N} / \mathrm{hr}$. It was found from a number of determinations that $1 \mathrm{mg}$. cell $\mathrm{N}$ was equivalent to $8.26 \mathrm{mg}$. dry weight.

Estimation of metabolites. Glycogen was estimated by the method of Good, Kramer \& Somogyi (1933). Using $\mathrm{Ba}(\mathrm{OH})_{2}-\mathrm{ZnSO}_{4}$ filtrates, reducing sugar was estimated iodometrically by the method of Somogyi (1945), lactic acid by the method of Barker \& Summerson (1941), ethanol by distillation and reduction of dichromate as described by Nicloux, le Breton \& Doutcheff (1934), and glycerol by the periodate method of Lambert \& Neish (1950), slightly modified. For this, the sample was made to $1.5 \mathrm{ml}$. with 
water, $0.5 \mathrm{ml} .2 \mathrm{~N}-\mathrm{H}_{2} \mathrm{SO}_{4}$ was added, followed by $0.5 \mathrm{ml}$. $0 \cdot 1 \mathrm{~m} \mathrm{NaIO}$. Exactly $5 \mathrm{~min}$. later, $0.5 \mathrm{ml} .13 \cdot 13 \%(\mathrm{w} / \mathrm{v})$ $\mathrm{NaAsO}_{2}$ was added, and after standing for 10 min., the mixture was diluted to $10 \mathrm{ml}$. with water. A $1 \mathrm{ml}$. sample of this was taken and heated with $10 \mathrm{ml}$. chromotropic acid reagent $(1.08 \mathrm{~g}$. $\mathrm{Na}$ salt of chromotropic acid in $100 \mathrm{ml}$. distilled water $+450 \mathrm{ml}$. $\left.65 \%(v / v) \mathrm{H}_{2} \mathrm{SO}_{4}\right)$ on a boilingwater bath for $30 \mathrm{~min}$. The tubes were cooled, and the colour measured in the Hilger Spekker absorptiometer using an Ilford 606 yellow filter (peak transmittance $580 \mathrm{~m} \mu$.) and a $1 \mathrm{~cm}$. cell. With each set of estimations, a series of nine standards was included, containing 0,50 and $100 \mu \mathrm{g}$. glycerol plus $0,0.5$ or $1.0 \mathrm{mg}$. glucose. During the $5 \mathrm{~min}$. period of the reaction, glucose is slightly degraded by periodate, and from the above standards, it was possible to apply a correction to the glycerol value after the glucose in the metabolic solution had been determined. Using trichloroacetic acid (TCA) filtrates, pyruvic acid was estimated by the method of Friedemann \& Haugen (1943), fructose by the method of Roe (1934) and phosphate fractions by the method of Fiske \& Subbarow (1925); total phosphorus was estimated after digestion with $60 \% \mathrm{HClO}_{4}$ and a little $\mathrm{HNO}_{3} . \quad \mathrm{P}_{0}$ represents inorganic phosphate estimated directly, $P_{7}$ and $P_{180}$ represent inorganic phosphate estimated after hydrolysis in $\mathrm{N}-\mathrm{HCl}$ at $100^{\circ}$ for 7 and $180 \mathrm{~min}$. respectively, while $P_{t}$ represents the total phosphate found after the $\mathrm{HClO}_{4}-\mathrm{HNO}_{3}$ digestion. Volatile acids were estimated by distillation and titration of a tungstic acid filtrate as described by Buchanan, Sakami, Gurin \& Wilson (1947); acid obtained by distillation in the presence of $\mathrm{HgO}$ was considered to be acetic, while acid recovered by distillation in the absence of $\mathrm{HgO}$ was considered to represent acetic + formic. Succinic acid was estimated manometrically by means of a washed pig-heart preparation of succinic oxidase.

\section{RESULTS}

\section{Aerobic metabolism}

Respiratory activity. Washed suspensions of Strigomonas oncopelti in the absence of extracellular nutrients respire and maintain motility for long periods; from a series of thirteen experiments, a $q_{\mathrm{O}_{2}}$ of 146 (range 103-236) was obtained $\left(Q_{\mathrm{O}_{2}}=17 \cdot 7\right.$ ). Estimations of intracellular glycogen gave values of 2.48 and $2.80 \%$ (on a dry-weight basis) for two 5 -day cultures. It is interesting to note that large amounts of soap were recovered after alkaline hydrolysis of the cells in the glycogen determinations. Experiments carried out in a Ringer-bicarbonate medium showed that this endogenous respiration did not involve the formation of acid, and took place with a respiratory quotient (R.Q.) of 0.9 (range 0.87-0.93).

On the addition of extracellular substrate, the respiration of the flagellate can be stimulated as much as fourfold. The twenty-three substances examined (at a concentration of $0.02 \mathrm{M}$ ) were divided into six groups: (a) Glucose, mannose and fructose stimulated respiration by $150-300 \%$, the actual stimulation varying from experiment to experiment. (b) L-Glutamate, glutamine, succinate and $\alpha$-oxoglutarate stimulated respiration by $100-$
$150 \%$. (c) DL-Aspartate, asparagine and lactate stimulated respiration by $50-100 \%$. (d) Ethanol DL-alanine, glycerol, lactose, sucrose, maltose, and galactose gave respiratory stimulations of up to $50 \%$. (e) Citrate, pyruvate, formate and butyrate were without effect on respiration. $(f)$ Acetate and propionate inhibited respiration by approximately $20 \%$.

Effect of inhibitors on respiration and motility. The sensitivity of endogenous and glucose-stimulated respiration to a number of inhibitors was investigated; the results are summarized in Table 1 . The experiments with cyanide were carried out using balanced $\mathrm{KOH}-\mathrm{KCN}$ mixtures in the centre well (Robbie, 1946). Cyanide did not exert any appreciable effect on motility until concentrations approaching $0.01 \mathrm{M}$ were used; at this concentration, especially in the absence of glucose, the flagellates became sluggish, showing a tendency to round off. On the whole, respiration of the flagellates was more sensitive to inhibitors than was their motility; in general, a large respiratory inhibition was usually accompanied by a small decrease in motility, with some rounding off of the cells, but only in the case of $0.01 \mathrm{~m}$ arsenite and the higher concentrations of 2:4-dinitrophenol, was complete immobilization of the cells obtained.

\section{Table 1. Effect of inhibitors on respiration}

Each manometer cup contained about $1 \mathrm{mg}$. cellular $\mathrm{N}$ in a total vol. of $1.5 \mathrm{ml}$; gas phase air; $\mathrm{pH} 7.3$ unless otherwise indicated; glucose present where shown in concentration of $0.02 \mathrm{~m} ; \%$ inhibition estimated over a $1 \mathrm{hr}$. period of respiration.

\begin{tabular}{|c|c|c|c|}
\hline \multicolumn{2}{|l|}{ perioa } & \multicolumn{2}{|c|}{ Inhibition (\%) } \\
\hline Inhibitor & $\begin{array}{c}\text { Concentration } \\
\text { (M) }\end{array}$ & $\begin{array}{c}\text { No } \\
\text { glucose }\end{array}$ & Glucose \\
\hline Potassium cyanide & $\left\{\begin{array}{l}0.46 \times 10^{-3} \\
10^{-4} \\
0.46 \times 10^{-4} \\
0.46 \times 10^{-5}\end{array}\right.$ & $\frac{76}{46}$ & $\begin{array}{l}88 \\
65 \\
37 \\
18\end{array}$ \\
\hline Hydroxylamine & 0.01 & 54 & 66 \\
\hline Sodium arsenite & $\left\{\begin{array}{c}0.01 \\
0.003 \\
0.001\end{array}\right.$ & $\overline{16}$ & $\begin{array}{l}79 \\
60 \\
24\end{array}$ \\
\hline Iodoacetate & 0.001 & 50 & 55 \\
\hline Sodium fluoride & 0.04 & - & $\mathbf{0}$ \\
\hline Sodium malonate & 0.04 & -6 & 0 \\
\hline Phenylthiourea & 0.001 & - & -5 \\
\hline 2:2'-Dipyridyl & 0.001 & -3 & 11 \\
\hline 8-Hydroxyquinoline & 0.001 & -7 & 17 \\
\hline & & $\begin{array}{l}\text { pH 5.5; } \\
\text { glucose }\end{array}$ & $\begin{array}{l}\text { pH } 6 \cdot 2 ; \\
\text { glucose }\end{array}$ \\
\hline Sodium azide & $\begin{array}{l}0.0003 \\
0.0001\end{array}$ & $\begin{array}{l}81 \\
67\end{array}$ & $\begin{array}{l}79 \\
33\end{array}$ \\
\hline 2:4-Dinitrophenol & $\begin{array}{l}0.003 \\
0.001 \\
0.0003 \\
0.0001\end{array}$ & $\begin{array}{l}96 \\
75 \\
75 \\
21\end{array}$ & $\begin{array}{r}77 \\
51 \\
25 \\
2\end{array}$ \\
\hline
\end{tabular}




\section{Haem compounds}

Spectroscopic observations. Direct spectroscopic examination of a well aerated suspension of the flagellates revealed no absorption bands; there was no indication of the presence of haemoglobin in the organism. On allowing the suspension to stand, absorption bands due to cytochrome pigments became apparent. Spectroscopic examination at room temperature of a cell suspension reduced with a little sodium dithionite $\left(\mathrm{Na}_{2} \mathrm{~S}_{2} \mathrm{O}_{4}\right)$ showed: (a) A strong band in the green, having its centre at $558 \mathrm{~m} \mu$., and extending over the range 552-564 $\mathrm{m} \mu$. This band was probably due to a modified $b$ component and/or an $e$ component. (b) A weaker $\beta$-band at 528-530 $\mathrm{m} \mu$. (c) An extremely weak band due to cytochrome $a$ at $605 \mathrm{~m} \mu$. Examination of a cell suspension in $50 \%$ glycerol after reduction, cooling in liquid nitrogen, devitrification and recooling, revealed a sharp, fine cytochrome $a$ band, and in addition, a sharp and quite intense band due to cytochrome $c$, well separated from the intense band in the green; placing a tube of frozen cytochrome $c$ in the light path did not displace, but merely intensified the $c$ band of the organism.

Manometric observations. A homogenate of $S$. oncopelti prepared in the Mickle disintegrator was able to catalyse the oxidation of $p$-phenylenediamine, succinate, lactate (Fig. 1), and also $p$ aminophenol. The oxidation of succinate and lactate was slightly stimulated by added cytochrome $c$, but this had no effect on the oxidation of $p$-phenylenediamine. However, if the homogenate was centrifuged, and the deposit washed and resuspended in Ringer-phosphate, the suspension would oxidize $p$-phenylenediamine $\left(q_{0}, 112\right)$, and the rate was stimulated $52 \%$ by $6.5 \times 10^{-5} \mathrm{M}$ cytochrome $c$. In connexion with the presence of cytochrome oxidase, the inhibitory effects of cyanide shown in Table 1 should be noted. Neither whole cells nor homogenates were able to decompose $\mathrm{H}_{2} \mathrm{O}_{2}$, indicating the absence of catalases. The flagellates were rapidly immobilized by $0.005 \mathrm{M}$ $\mathrm{H}_{2} \mathrm{O}_{2}$.

\section{Anaerobic metabolism}

Under anaerobic conditions in the absence of extracellular substrates the flagellates are metabolically inactive, and over a period of about 30 min., gradually lose their motility. In the presence of glucose, fructose or mannose, but not with other mono- or di-saccharides tested, the cells show vigorous motility, and liberate carbon dioxide when suspended in a Ringer-bicarbonate medium;

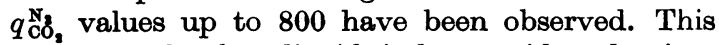
evolution of carbon dioxide is due to acid production, plus the balance of carbon dioxide formed by fermentation, and that assimilated. The sensitivity of this carbon dioxide production to a number of inhibitors was tested; the results are summarized in Table 2. From this, it can be seen that the fermentation was little affected by cyanide, azide fluoride or phenylthiourea, was inhibited by rather high concentrations of arsenite or iodoacetate, while a quite

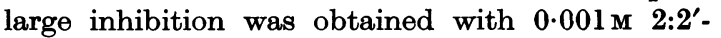
dipyridyl or 8-hydroxyquinoline.

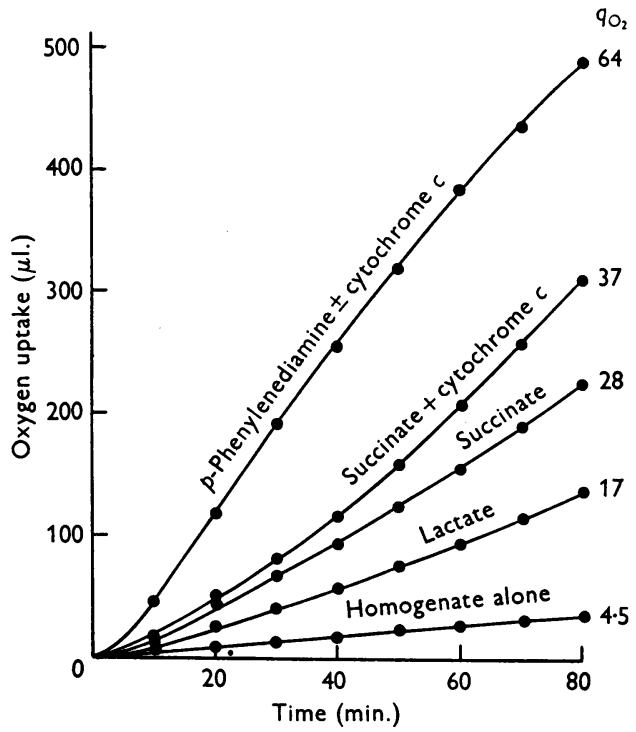

Fig. 1. Oxidase activity in S. oncopelti homogenate. Each manometer cup contained $6.4 \mathrm{mg}$. homogenate $\mathrm{N}$ and $0.025 \mathrm{M}$ phosphate buffer in a total vol. of $2.5 \mathrm{ml}$.; gas phase $\mathrm{CO}_{2}$-free air. Succinate or lactate tipped from side bulb to give conc. of $0.03 \mathrm{M} ; p$-phenylenediamine added at rate of $13 \mathrm{mg}$./cup; cytochrome $c$ when present in conc. of $6.5 \times 10^{-5} \mathrm{M}$. Oxygen uptake of $p$-phenylenediamine + cyt. $c$ without homogenate over $80 \mathrm{~min}$. period $9 \mu \mathrm{l}$; $q_{\mathrm{o}_{2}}$ of system containing lactate + cyt. $c$ (not shown) 20 .

\section{Table 2. Effect of inhibitors on anaerobic metabolism}

Each manometer cup contained about $0.5 \mathrm{mg}$. cellular $\mathrm{N}$ in a total vol. of $1.5 \mathrm{ml}$.; glucose present at concentration of $0.02 \mathrm{M}$; gas phase $5 \% \mathrm{CO}_{2}-95 \% \mathrm{~N}_{2}$. Inhibitor added from side bulb, and inhibition of $\mathrm{CO}_{2}$ production estimated over period of $1 \mathrm{hr}$.

\begin{tabular}{|c|c|c|}
\hline Inhibitor & $\begin{array}{c}\text { Concn. } \\
\text { (M) }\end{array}$ & $\begin{array}{c}\text { Inhibition } \\
(\%)\end{array}$ \\
\hline Potassium cyanide & 0.01 & 0 \\
\hline Sodium azide & $\begin{array}{l}0.04 \\
0 \cdot 01\end{array}$ & $\begin{array}{l}41 \\
26\end{array}$ \\
\hline Sodium arsenite & $\begin{array}{l}0.02 \\
0.01\end{array}$ & $\begin{array}{l}46 \\
26\end{array}$ \\
\hline Iodoacetate & $\begin{array}{l}0.01 \\
0.002 \\
0.001\end{array}$ & $\begin{array}{l}79 \\
47 \\
25\end{array}$ \\
\hline Sodium fluoride & 0.02 & 19 \\
\hline Phenylthiourea & 0.001 & 0 \\
\hline 2:2'-Dipyridyl & 0.001 & 81 \\
\hline 8-Hydroxyquinoline & $0 \cdot 001$ & 66 \\
\hline
\end{tabular}




\section{Glucose metabolism}

Although endogenous respiration of $S$. oncopelti takes place with a respiratory quotient of 0.9 , much higher values were obtained for respiration in the presence of glucose. Using the method of Dickens $\&$ Simer with cells in a Ringer-bicarbonate medium, R.Q.'s up to 2.4 have been obtained; in general young cultures (3-4 days) showed a high R.Q., while older cultures (6-7 days) gave R.Q.'s just greater than unity. Cultures of the flagellate grown in the presence of glucose smell remarkably like yeast; examination of metabolic solutions showed that glucose was fermented to a mixture of organic acids, mainly succinic and pyruvic, together with appreciable quantities of ethanol and glycerol.

Conditions affecting the rate of glucose utilization by the flagellate were investigated in washed suspensions. From Table 3 it can be seen that glucose utilization under both aerobic and anaerobic conditions was stimulated by carbon dioxide, and that in

\section{Table 3. Effect of environment on glucose metabolism}

Each manometer cup contained $0.68 \mathrm{mg}$. cellular $\mathrm{N}$ in a total vol. of $1.5 \mathrm{ml}$; phosphate or bicarbonate buffer as appropriate; glucose (15 $\mu$ moles) tipped from side bulb at beginning, and fermentation stopped after $40 \mathrm{~min}$. incubation by $0.2 \mathrm{ml} .2 \mathrm{~N}-\mathrm{H}_{2} \mathrm{SO}_{4}$ tipped from second side bulb.

$\begin{array}{lccc}\text { System } & \begin{array}{c}\text { Glucose } \\ \text { used } \\ (\mu \text { moles })\end{array} & \begin{array}{c}\text { Succinic } \\ \text { acid } \\ \text { formed } \\ (\mu \text { moles })\end{array} & \begin{array}{c}\text { Total } \\ \text { acid } \\ \text { formed } \\ (\mu \text { equiv. })\end{array} \\ \mathrm{N}_{2} & 4 \cdot 98 & 0 \cdot 63 & - \\ \mathrm{N}_{2}+0.02 \mathrm{M} \mathrm{pyruvate} & 5 \cdot 35 & 0 \cdot 64 & - \\ \mathrm{N}_{2}+5 \% \mathrm{CO}_{2} & 10 \cdot 15 & 2 \cdot 31 & 12.37 \\ \mathrm{CO}_{2}-\text { free air } & 5 \cdot 49 & 0.00 & - \\ \text { Air }+5 \% \mathrm{Co}_{2} & \mathbf{8 . 2 6} & 0.50 & 3.97\end{array}$

the presence of carbon dioxide, more glucose was destroyed anaerobically than aerobically; carbon dioxide stimulated the production of succinic acid, especially under anaerobic conditions.

Using the method of Dickens \& Šimer, it was shown that the only gas produced by anaerobic glucose metabolism in a Ringer-bicarbonate medium, was carbon dioxide. Similar experiments with Trypanosoma lewisi and Tetrahymena pyriformis (GL) gave the same result, but in the case of Trichomonas foetus (Ryley, 1955), another gas, doubtless hydrogen, was produced in addition to carbon dioxide. The products of glucose metabolism under both aerobic and anaerobic conditions were examined in the case of cells in carbon dioxidebicarbonate systems. Although the actual yields of the various metabolites were variable from experiment to experiment, owing to harvesting the cells at different times in the growth cycle, the same overall picture was obtained. A typical series of results is summarized in Table 4, from which it can be seen that most of the acid was accounted for by pyruvic and succinic acids, and that appreciable amounts of ethanol, and also glycerol were produced; there was always more glycerol and less succinic acid produced under aerobic than anaerobic conditions. On some occasions the yields of ethanol were smaller, and those of succinate larger; when this difference was sufficiently pronounced, there was a net fixation rather than a production of carbon dioxide. Although the amounts of metabolic solution available in the above experiments were not large enough to allow the simultaneous estimation of volatile acids, similar experiments showed that not more than $0 \cdot 1$ mole volatile acid, and usually less was produced per mole glucose degraded under either aerobic or anaerobic conditions.

Table 4. Metabolic products formed during aerobic and anaerobic glucose breakdown

Cellular N (5.16 mg.) in total vol. of 6.0 ml. Ringer-bicarbonate distributed in 3 Dickens \& Simer or 4 Warburg manometer flasks; glucose initially present $90 \mu$ moles; gas phase air or $\mathrm{N}_{2}$, both containing $5 \% \mathrm{CO}_{2}$. Fermentation stopped after $20 \mathrm{~min}$. with acid, flask contents neutralized, and samples taken for estimation of various metabolites. Aerobically $39 \cdot 35 \mu$ moles glucose and $15 \cdot 1 \mu$ moles $\mathrm{O}_{2}$ used with the formation of $39 \cdot 6 \mu$ equiv. acid. Anaerobically $47 \cdot 6 \mu \mathrm{moles}$ glucose used with the production of $49 \cdot 0 \mu$ equiv. acid. Yields expressed in terms of moles metabolite found/mole glucose disappearing, from which values for carbon and acid recoveries have been calculated. Redox values have been calculated by the method of Johnson, Peterson \& Fred (1931); the substrate glucose has a redox value of 0 .

\begin{tabular}{|c|c|c|c|c|c|c|c|c|}
\hline \multirow[b]{3}{*}{ Metabolite } & \multicolumn{3}{|c|}{ Aerobically } & \multicolumn{5}{|c|}{ Anaerobically } \\
\hline & & & Acid & & & Acid & Red & lues \\
\hline & Moles & $\begin{array}{l}\text { C atoms } \\
\text { (g. atoms) }\end{array}$ & $\begin{array}{l}\text { equiv. } \\
\text { (g. equiv.) }\end{array}$ & Moles & $\begin{array}{c}\text { C atoms } \\
\text { (g. atoms) }\end{array}$ & $\begin{array}{l}\text { equiv. } \\
\text { (g. equiv.) }\end{array}$ & (-) & $(+)$ \\
\hline Carbon dioxide & 0.95 & 0.95 & - & 0.46 & 0.46 & - & 0.92 & - \\
\hline Ethanol & 0.91 & $1 \cdot 82$ & 一 & 0.58 & $1 \cdot 16$ & - & 一 & $1 \cdot 16$ \\
\hline Glycerol & 0.32 & 0.96 & - & $0 \cdot 16$ & 0.48 & - & - & $0 \cdot 16$ \\
\hline Lactic acid & 0.01 & 0.03 & 0.01 & 0.02 & 0.05 & 0.02 & 0 & $\mathbf{0}$ \\
\hline Pyruvic acid & $0 \cdot 28$ & $0 \cdot 84$ & $0 \cdot 28$ & $0 \cdot 21$ & $0 \cdot 63$ & $0 \cdot 21$ & $0 \cdot 21$ & - \\
\hline Succinic acid & $0 \cdot 22$ & $0 \cdot 88$ & 0.44 & $0 \cdot 43$ & $1 \cdot 72$ & 0.86 & 0.43 & - \\
\hline Sum & - & $5 \cdot 48$ & 0.73 & - & $4 \cdot 51$ & 1.09 & 1.56 & $1 \cdot 32$ \\
\hline C atoms supplied & - & $6 \cdot 00$ & - & - & 6.00 & - & - & - \\
\hline Acid yield (from bicarbona & - & - & $1 \cdot 01$ & - & - & 1.08 & - & - \\
\hline
\end{tabular}




\section{Intermediary glucose metabolism}

Using homogenates of the flagellates prepared in the Mickle disintegrator, experiments were carried out to demonstrate the presence of several phosphorylating and dehydrogenase systems. In view of the marked inhibition of anaerobic metabolism (Table 2) produced by 2:2' -dipyridyl and 8-hydroxyquinoline, attempts were made to discover the point of attack of these metal-binding substances. In agreement with the low respiratory stimulation produced by maltose, and the low glycogen content of the cells, no maltase, amylase or phosphorylase activity could be demonstrated in homogenates.

Hexokinase. Hexokinase activity was demonstrated by the liberation of carbon dioxide from a bicarbonate buffer in the presence of glucose and ATP. From Table 5 it can be seen that $44 \%$ of the glucose initially present in the system was esterified, $42 \%$ of the sugar phosphate being recovered as phosphofructose, while some of the ATP was hydrolysed, both in the presence and in the absence of glucose, with the liberation of inorganic phosphate. The rate of the hexokinase reaction was not influenced by $0.005 \mathrm{M} 2: 2^{\prime}$-dipyridyl; on adding dipyridyl to the homogenate, a deep pink colour was produced, indicating the presence of ferrous iron.

Phosphoglucomutase and ketoisomerase. The ability of $S$. oncopelti to transform glucose 1-phosphate into a mixture of hexose 6-phosphates has been shown directly by incubating Cori ester with a homogenate

\section{Table 5. Hexokinase activity in \\ S. oncopelti homogenate}

Each manometer cup contained $1.8 \mathrm{mg}$. homogenate $\mathrm{N}$, $0.06 \mathrm{M}-\mathrm{NaF}, 0.005 \mathrm{M}-\mathrm{MgSO}_{4}$ and $0.025 \mathrm{M}-\mathrm{NaHCO}_{3}$ in vol. of $2.4 \mathrm{ml}$; gas phase $5 \% \mathrm{CO}_{2}-95 \% \mathrm{~N}_{2}$. ATP (10.75 $\mu$ moles) and glucose $(11.1 \mu$ moles) added at beginning of experiments and reaction stopped at the end by $0.3 \mathrm{ml}$. $2 \mathrm{~N}$ $\mathrm{H}_{2} \mathrm{SO}_{4}$. Manometer contents neutralized; glucose estimated in $\mathrm{Ba}(\mathrm{OH})_{2}-\mathrm{ZnSO}_{4}$ filtrates, and fructose and acid-labile phosphate in TCA filtrates. Figures represent $\mu$ moles.

$\begin{array}{llc}\text { Glucose used } & \mathbf{4 \cdot 8 5} & - \\ \text { ATP used }\left[\mathrm{P}_{7}-\mathrm{P}_{0}\right] & \mathbf{5 \cdot 4 9} & \mathbf{2 \cdot 9 6} \\ \text { Ester-P formed } & \mathbf{3 \cdot 4 9} & \mathbf{0 \cdot 2 2} \\ \mathrm{P}_{0} \text { liberated } & \mathbf{2 \cdot 0 0} & \mathbf{2 \cdot 7 4} \\ \text { Fructose 6-phosphate formed } & \mathbf{1 . 4 6} & \mathbf{0 . 0 0} \\ \mathrm{CO}_{2} \text { evolved } & \mathbf{6 \cdot 5 2} & \mathbf{3 \cdot 4 0}\end{array}$

of the flagellate; evidence for this is presented in Table 6.

Fructose diphosphate metabolism. Aldolase activity, by which fructose diphosphate (FDP) is converted into triose phosphate (alkali-labile phosphate), was demonstrated in homogenates of $S$. oncopelti at $\mathrm{pH} 6 \cdot 0$. As can be seen from Table 7 , the reaction rate was little influenced by the presence of $0.06 \mathrm{M}-\mathrm{KCN}$ and/or $0.005 \mathrm{~m} \quad 2: 2^{\prime}$-dipyridyl, although in the presence of cyanide, which acts as a keto-fixative, more FDP was eventually degraded to triose phosphate.

Fig. 2 illustrates an experiment in which an attempt was made to show the coupling of the oxidation of triose phosphate with the reduction of pyruvate. Fluoride was added to inhibit enolase, and thus cause an accumulation of phosphoglyceric acid; the overall reaction should result in the production of acid, indicated by the liberation of carbon dioxide from a bicarbonate buffer. From the curve it can be seen that the homogenate showed an endogenous fermentation of unknown nature, and that the oxido-reduction was dependent on the presence of added cozymase, was inhibited by $0.001 \mathrm{~m}$ iodoacetate, and was stimulated by $0.004 \mathrm{M}$ arsenate. The omission of pyruvate from the system had no effect; lactic acid analyses carried out at the end of the experiment showed that none of this substance was formed during the oxido-reduction. The analyses for fructose and phosphorus indicate that the utilization of FDP paralleled the production of acid, and that in the presence of iodoacetate or in the absence of cozymase, most of the FDP utilized was recovered in the form of triose phosphate, while with the complete system, with or without arsenate, most of the FDP was degraded beyond the triose phosphate stage. At the end of the experiment, the remainder of the TCA filtrate was fractionated to give the barium-insoluble fraction. Although fructose analyses on this fraction showed that much had been lost, there was found to be an accumulation of phosphoglyceric acid in the complete system, and a larger accumulation in the presence of arsenate; this was shown by an increase in phosphate resistant to hydrolysis for $6 \mathrm{hr}$. in $\mathrm{N}-\mathrm{HCl}$, and by the colorimetric method of Rapoport (1937), which gave only a qualitative result as no standard of phosphoglyceric acid was available. The

Table 6. Phosphoglucomutase and ketoisomerase activity in S. oncopelti homogenates

Each tube contained 3.2 mg. homogenate $\mathrm{N}, 0.002 \mathrm{M} \mathrm{MgCl}_{2}, 0.02 \mathrm{M}$ acetate-veronal buffer (pH 7.3) and $3 \mathrm{mg}$. K glucose 1-phosphate (G 1-P) in a total vol. of $4.5 \mathrm{ml}$. Tubes deproteinized with $1.5 \mathrm{ml} .10 \%$ TCA after 10 or 60 min. incubation at $30^{\circ}$. Figures represent changes in various phosphate fractions expressed in $\mu$ moles. Fructose 6-phosphate (F 6-P) from fructose content of TCA filtrate.

\begin{tabular}{|c|c|c|c|c|c|}
\hline $\begin{array}{c}\text { Time } \\
\text { (min.) }\end{array}$ & {$\left[\mathbf{P}_{0}\right]$} & $\begin{array}{l}{\left[\mathrm{P}_{7}-\mathrm{P}_{0}\right]} \\
(\mathrm{G} 1-\mathrm{P})\end{array}$ & {$\left[\mathbf{P}_{180}-\mathbf{P}_{7}\right]$} & {$\left[\mathrm{P}_{t}-\mathrm{P}_{180}\right]$} & F 6-P \\
\hline $\begin{array}{l}10 \\
60\end{array}$ & $\begin{array}{l}+1 \cdot 38 \\
+2 \cdot 70\end{array}$ & $\begin{array}{l}-2 \cdot 30 \\
-6 \cdot 40\end{array}$ & $\begin{array}{r}+0.40 \\
+0.75\end{array}$ & $\begin{array}{l}+0.52 \\
+2.95\end{array}$ & $\begin{array}{l}+0.28 \\
+2.03\end{array}$ \\
\hline
\end{tabular}


Table 7. Aldolase activity in S. oncopelti homogenates

Tubes were set up to contain $2 \cdot 2 \mathrm{mg}$. homogenate $\mathrm{N}, 0 \cdot 011 \mathrm{M}$ acetate-veronal buffer $\mathrm{pH} 6 \cdot 0,0 \cdot 06 \mathrm{M}-\mathrm{NaF}, 0 \cdot 004 \mathrm{M}$ fructose 1:6-diphosphate (FDP) and 0.06 M-KCN and 0.005 $2: 2^{\prime}$-dipyridyl where indicated in total vol. of $10 \mathrm{ml}$. Samples (2 ml.) removed into $2 \mathrm{ml} .7 \cdot 7 \%$ TCA after incubation at $30^{\circ}$ for various intervals. Figures represent $\mu$ moles FDP used (from fructose estimations) or triose phosphate (alkali-labile) formed.

\begin{tabular}{|c|c|c|c|c|}
\hline \multirow{2}{*}{$\begin{array}{l}\text { Timine } \\
\text { (min.) }\end{array}$} & \multicolumn{2}{|c|}{ FDP used } & \multicolumn{2}{|c|}{ Triose $\mathbf{P}$ formed } \\
\hline & Control & 2:2'-Dipyridyl & Control & 2:2'-Dipyridyl \\
\hline $\begin{array}{l}\text { No } \mathrm{KCN} \\
2 \\
10\end{array}$ & $\begin{array}{l}4 \cdot 90 \\
6 \cdot 60 \\
6 \cdot 90\end{array}$ & $\begin{array}{l}\mathbf{4} \cdot 90 \\
\mathbf{6} \cdot 20 \\
\mathbf{7} \cdot \mathbf{3 5}\end{array}$ & $\begin{array}{r}8 \cdot 56 \\
11 \cdot 23 \\
11 \cdot 80\end{array}$ & $\begin{array}{r}6 \cdot 90 \\
11 \cdot 03 \\
12 \cdot 82\end{array}$ \\
\hline $\mathrm{KCN}$ & $\begin{array}{r}4 \cdot 25 \\
6 \cdot 40 \\
11 \cdot 10\end{array}$ & $\begin{array}{r}4 \cdot 50 \\
6 \cdot 20 \\
10 \cdot 70\end{array}$ & $\begin{array}{r}5 \cdot 14 \\
9 \cdot 36 \\
18 \cdot 16\end{array}$ & $\begin{array}{r}5 \cdot 84 \\
9 \cdot 51 \\
17 \cdot 69\end{array}$ \\
\hline
\end{tabular}

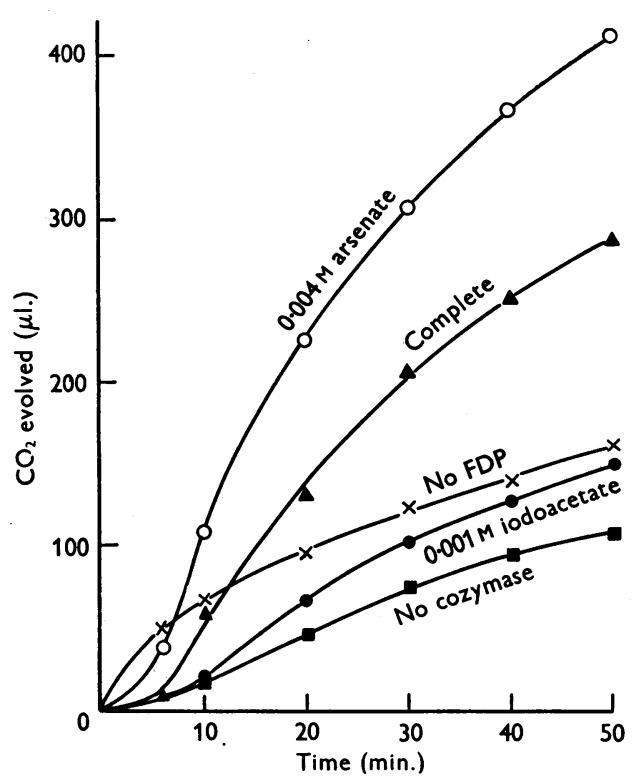

Fig. 2. Fructose diphosphate metabolism by $S$. oncopelti homogenate. Each curve represents $\mathrm{CO}_{2}$ evolution from $0.025 \mathrm{M}-\mathrm{NaHCO}_{3}$ containing $0.008 \mathrm{M} \mathrm{FDP}, 0.06 \mathrm{M}-\mathrm{NaF}$, $2 \mathrm{mg}$. impure cozymase, $0.008 \mathrm{M}$ pyruvate and $8.4 \mathrm{mg}$. homogenate $\mathrm{N}$ in a total vol. of $5.2 \mathrm{ml}$. distributed between two manometers; gas phase $5 \% \mathrm{CO}_{2}-95 \% \mathrm{~N}_{2}$. Presence of $0.004 \mathrm{~m}$ sodium arsenate or $0.001 \mathrm{~m}$ iodoacetate as indicated. Reaction started by adding FDP from side bulb; at end, $1.5 \mathrm{ml} .10 \%$ TCA added to each cup, and supernatant after centrifuging assayed for fructose and various phosphorus fractions.

$\begin{array}{lccc}\text { System } & \begin{array}{c}\text { FDP } \\ \text { used } \\ (\mu \mathrm{moles})\end{array} & \begin{array}{c}\text { Triose P } \\ \text { formed } \\ (\mu \mathrm{moles})\end{array} & \begin{array}{c}\text { FDP } \\ \text { fermented } \\ (\mu \mathrm{moles})\end{array} \\ \text { Complete } & 16 \cdot 35 & 11 \cdot 70 & 10 \cdot 50 \\ \text { No cozymase } & 7 \cdot 60 & 15 \cdot 02 & 0 \cdot 09 \\ \text { 0.001 M Iodoacetate } & \mathbf{8 \cdot 7 5} & 14 \cdot 50 & 1 \cdot 50 \\ 0 \cdot 004 \text { M Arsenate } & \mathbf{2 4 \cdot 7 8} & 5 \cdot 18 & 22 \cdot 19\end{array}$

rate of the oxido-reduction reaction, as measured by acid production, was consistently found to be inhibited $31 \%$ by the presence of $0.005 \mathrm{M} 2: 2^{\prime}$ - dipyridyl; this inhibition remained unchanged with twice the concentration of dipyridyl.

Carboxylase. It was found that homogenates of $S$. oncopelti in phosphate buffer, $\mathrm{pH} 6 \cdot 8$, were able to degrade pyruvate with the formation of carbon dioxide. The reaction gave the theoretical yield of carbon dioxide in the presence of a nitrogen gas phase; with a gas phase of air, the carbon dioxide yield was reduced to $87 \%$. The rate of pyruvate breakdown was slightly stimulated by preincubation of the homogenate with ATP and thiamine.

Dehydrogenases. Homogenates of the flagellate were earlier shown to oxidize lactate and succinate (Fig. 1). The ability of such homogenates to oxidize these and some other substrates using methylene blue as hydrogen acceptor has been tested by the Thunberg technique. From Table 8 it can be seen that lactate and fumarate considerably accelerated the reduction of methylene blue, while succinate and ethanol caused a slight stimulation of the reduction; formate, FDP and glucose were without effect. The presence of lactic and succinic dehydrogenases, and fumarase + malic dehydrogenase was also demonstrated by the manometric technique of Quastel \& Wheatley (1938), using ferricyanide as hydrogen acceptor. In this system, as can be seen from Fig. 3, the activity of lactic and succinic dehydrogenases was marked, while fumarase + malic dehydrogenase activity was rather low.

\section{DISCUSSION}

In contrast to the animal trypanosomes, Strigomonas oncopelti is able to maintain respiration and motility for some time in the absence of extracellular substrates. Although the flagellate contains a small amount of material estimated as glycogen, the fact that endogenous respiration takes place with an R.Q. of 0.9 , and does not involve the production of acid suggests that some other endogenous substrate is being utilized. A similar situation exists with the ciliate Tetrahymena pyriformis (Ryley, 1952) where, although the cells contain about $20 \%$ of glycogen, these reserves are only 
metabolized under anaerobic conditions, some other intracellular substrate being responsible for endogenous respiration. With the flagellate Trichomonas foetus, on the other hand (Ryley, 1955), both aerobic and anaerobic endogenous metabolism depend on intracellular glycogen. A number of substances, particularly hexoses, are able to stimulate the respiration of $S$. oncopelti considerably, although motility does not increase perceptibly. Succinate more than doubles respiration; this may be compared with the flagellate Trypanosoma lewisi

\section{Table 8. Dehydrogenase activity in}

\section{S. oncopelti homogenates}

Thunberg tubes contained $4 \mathrm{ml}$. homogenate ( $\mathrm{N}$ content as indicated) in $0.024 \mathrm{M}$ phosphate buffer ( $\mathrm{pH} \mathrm{7 \cdot 3)}$. Tubes evacuated and washed with pure $\mathrm{N}_{2} 4$ times. Methylene blue $(0 \cdot 134 \mu$ moles $)$ and $75 \mu$ moles substrate as indicated added from hollow stopper. Figures give time (min.) for $90 \%$ decolorization.

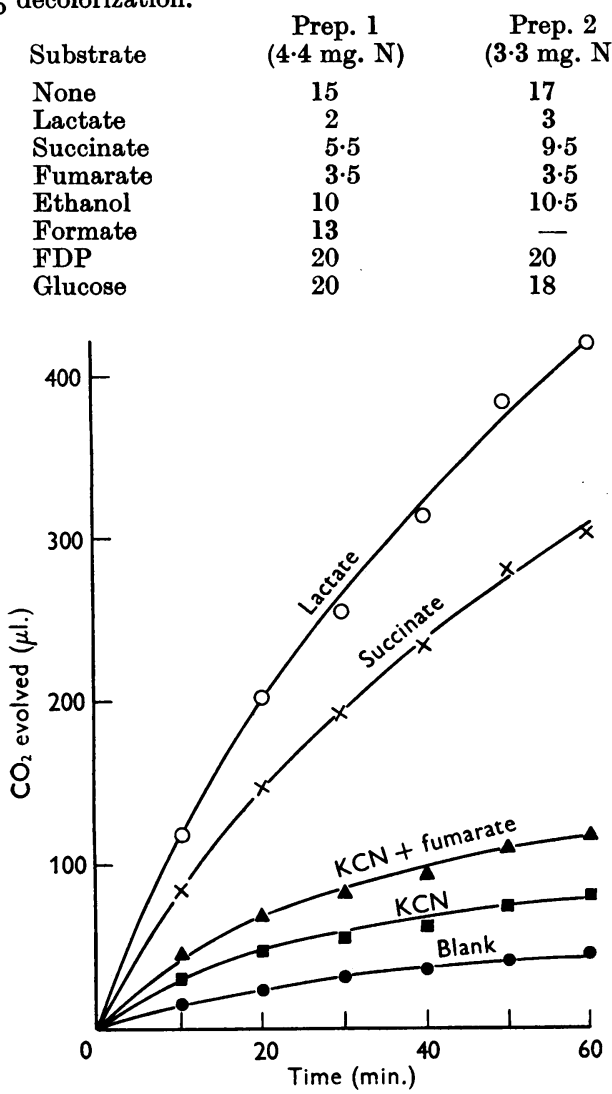

Fig. 3. Dehydrogenase activity of $S$. oncopelti homogenate. Each manometer cup contained $0.02 \mathrm{M}-\mathrm{NaHCO}_{3}, 0.2 \mathrm{ml}$. $11 \%(w / v) \mathrm{K}_{3} \mathrm{Fe}(\mathrm{CN})_{B}, 0.08 \mathrm{M}$ succinate, lactate or fumarate and $1.6 \mathrm{mg}$. homogenate $\mathrm{N}$ in a total vol. of $2.5 \mathrm{ml}$; in addition, two of the manometers contained $0.05 \mathrm{M}-\mathrm{KCN}, 0.03 \mathrm{M}$ nicotinamide and $0.4 \mathrm{mg}$. crude cozymase as indicated; gas phase $5 \% \mathrm{CO}_{2}-95 \% \mathrm{~N}_{2}$.
(Ryley, 1951) which, although it produces succinate during anaerobic glucose metabolism, is unable to oxidize added succinate, unless the cell membrane is destroyed.

Spectroscopic examination of $S$. oncopelti reveals the presence of a cytochrome system very similar to that of $T$. lewisi. A. Lwoff (1934) examined the flagellate $S$. fasciculata, but only found absorption bands at 555 and $530 \mathrm{~m} \mu$.; it seems likely that the methods used were not sensitive enough to detect the fainter $c$ and $a$ bands whose presence was suggested by inhibitor experiments; thus in the present study, the cytochrome $c$ band only became readily visible after cooling the cell suspension in liquid nitrogen. The presence of cytochrome oxidase is confirmed by the manometric experiments illustrated in Fig. 1; the fact that the oxidation of $p$ phenylenediamine was not stimulated by added cytochrome $c$ unless the particulate preparation was first washed suggests that the ratios of cytochromes $a$ to $c$ is greater than for $T$. lewisi. The oxidation of succinate and lactate by homogenates was also stimulated by added cytochrome c. Succinic oxidase activity was greater than lactic oxidase activity, although when assayed by either the manometric or Thunberg tube techniques, lactic dehydrogenase activity was found to be greater than succinic dehydrogenase activity. The presence of such an active lactic dehydrogenase is rather interesting, as significant amounts of lactic acid failed to accumulate during glucose fermentation under either aerobic or anaerobic conditions.

In contrast to its aerobic metabolism, motility and metabolism of $S$. oncopelti under anaerobic conditions depends on the presence of utilizable extracellular carbohydrate. Anaerobically glucose is fermented to a mixture of pyruvic and succinic acids, ethanol, glycerol and carbon dioxide. Under aerobic conditions, glucose fermentation is very pronounced, although succinate production is somewhat decreased, and this vigorous fermentation explains the high respiratory quotients observed in the presence of glucose-up to 2.4 with cells harvested early in the growth period. A. Lwoff (1934) observed an R.Q. of 1.0 for $S$. oncopelti, which suggests that he was dealing with much older cells. Succinate production involves the assimilation of carbon dioxide, although the overall fermentation results in a net production of carbon dioxide, and both glucose utilization and succinate production are considerably stimulated by the presence of carbon dioxide in the gas phase. The formation of glycerol and ethanol during the course of fermentation is interesting. Glycerol production among the Protozoa has been reported for Trypanosoma brucei (Glowazky, 1937) and for T. equiperdum (Reiner, Smythe \& Pedlow, 1936) under anaerobic conditions, while ethanol was detected during anaerobic 
glucose metabolism by T. lewisi (Reiner et al. 1936); the amounts of ethanol produced by $T$. lewisi, and also by Tetrahymena pyriformis were shown by Ryley $(1951,1952)$ to be extremely small. Fulton \& Stevens (1945) reported that $T$. rhodesiense produced among many other metabolites glycerol and ethanol; their results however were only of a qualitative nature. Preliminary quantitative experiments indicate that glycerol and pyruvic acid are the main products of aerobic or anaerobic glucose metabolism by $T$. rhodesiense.

Anaerobic glucose fermentation by $S$. oncopelti was remarkably resistant to a variety of inhibitors tested, the most effective substance being $2: 2^{\prime}$ dipyridyl, which at a concentration of $0.001 \mathrm{~m}$ reduced carbon dioxide production by $81 \%$. Using this inhibitor with cell-free preparations, it was found that the hexokinase and aldolase systems were insensitive, while there was only a $31 \%$ inhibition of triose phosphate fermentation. In this respect, the aldolase of the flagellate resembles the animal rather than the yeast type of enzyme (Warburg \& Christian, 1943).

Cell homogenates are able to ferment hexose diphosphate with the production of acid, including phosphoglyceric acid. This reaction takes place in the presence of $0.06 \mathrm{M}$ fluoride, and is independent of the addition of pyruvate. The experiment illustrated in Fig. 2 was carried out in an attempt to demonstrate the oxidation of triose phosphate coupled to the reduction of pyruvate. Since added pyruvate was not necessary to the fermentation, it seems possible that the enolase system of the flagellate is insensitive to fluoride, and formed rather than added pyruvate is utilized in the reoxidation of cozymase. An alternative explanation is that fluoride inhibits the protozoal enolase, and that the observed acid production is due to an oxido-reduction reaction between two moles of triose phosphate, giving rise to a mixture of $\alpha$ glycerophosphate and 3-phosphoglyceric acid. This idea is supported by the fact that glycerol accumulates during glucose metabolism, and can stimulate endogenous cellular respiration, but it does not explain the stimulation of hexose diphosphate fermentation produced by arsenate. It should be noted that a similar situation exists with Trichomonas foetus (Ryley, 1955); this organism can neither produce nor utilize glycerol, but homogenates can ferment hexose diphosphate in the presence of fluoride, no matter whether pyruvate is added or not.

\section{SUMMARY}

1. The parasitic flagellate Strigomonas oncopelti can respire and maintain motility under aerobic conditions for several hours in the absence of extracellular substrates. This respiration takes place with a $q_{\mathrm{O}_{2}}$ of about 146 at $30^{\circ}$ and an R.Q. of 0.9 .

2. Respiration of the flagellate is considerably stimulated by glucose, fructose, mannose, Lglutamate, glutamine, succinate, $\alpha$-oxoglutarate, DL-aspartate, asparagine and lactate while DLalanine, ethanol, glycerol, galactose, lactose, sucrose and maltose stimulate respiration to a lesser extent. Citrate, pyruvate and short-chain fatty acids either have no effect or produce a small inhibition of respiration.

3. Respiration of $S$. oncopelti is mediated to a large extent by the cytochrome system. Cytochromes $a, b$ and $c$ have been demonstrated spectroscopically, and cytochrome oxidase and succinic oxidase activity has been shown in cell homogenates.

4. Respiration, and to a lesser extent motility, is quite sensitive to cyanide, azide and 2:4-dinitrophenol.

5. Under anaerobic conditions, metabolism and motility depend on the availability of utilizable extracellular carbohydrate; in a Ringer-bicarbonate medium in the presence of glucose, $q_{\mathrm{Co}}^{\mathrm{N}}$, values of up to 800 have been observed. This fermentation is appreciably inhibited by $2: 2^{\prime}$-dipyridyl.

6. Under both aerobic and anaerobic conditions, glucose is degraded to a mixture of ethanol, glycerol, succinic and pyruvic acids and carbon dioxide.

7. Using homogenates of $S$. oncopelti, the flagellate has been shown to contain hexokinase, phosphoglucomutase and ketoisomerase, aldolase, a triose phosphate oxidizing system, carboxylase, succinic, lactic and malic dehydrogenases and fumarase.

I should like to thank Miss Margaret Mitchell for her invaluable technical assistance.

\section{REFERENCES}

Barker, S. B. \& Summerson, W. H. (1941). J. biol. Chem. 138, 535.

Buchanan, J. M., Sakami, W., Gurin, S. \& Wilson, D. W. (1947). J. biol. Chem. 169, 403.

Dixon, M. (1934). Manometric Methods, p. 87. Cambridge University Press.

Fiske, C. H. \& Subbarow, Y. (1925). J. biol. Chem. 66, 375. Friedemann, T. E. \& Haugen, G. E. (1943). J. biol. Chem. $147,415$.

Fulton, J. D. \& Stevens, T. S. (1945). Biochem. J. 39, 317. Glowazky, F. (1937). Z. Hyg. InfektKr. 119, 741.

Good, C. A., Kramer, H. \& Somogyi, M. (1933). J.biol. Chem. $100,485$.

Johnson, M. J., Peterson, W. H. \& Fred, E. B. (1931). J. biol. Chem. 91, 569.

Keilin, D. \& Hartree, E. F. (1937). Proc. Roy. Soc. B, 122, 298.

Keilin, D. \& Hartree, E. F. (1949). Nature, Lond., 164, 254. Keilin, D. \& Hartree, E. F. (1950). Nature, Lond., 165, 504. 
Lambert, M. \& Neish, A. C. (1950). Canad.J. Res. B, $28,83$. LePage, G. A. (1945). In Umbreit, W. W., Burris, R. H. \& Stauffer, J. F., Manometric Techniques and Related Methods for the Study of Tissue Metabolism, p. 181. Minneapolis: Burgess Publishing Co.

LePage, G. A. (1949). Biochem. Prep. 1, 28.

Lwoff, A. (1934). Zbl. Bakt. (1. Abt.), 130, 498.

Lwoff, M. (1940). Recherches sur le pouvoir de synthèse des Flagellés Trypanosomides, p. 26. Paris: Masson.

Lwoff, M. (1951). Biochemistry and Physiology of Protozoa (ed. A. Lwoff), 1, 129. New York: Academic Press.

Nicloux, M., le Breton, E. \& Doutcheff, A. (1934). Bull. Soc. Chim. biol., Paris, 16, 1314.
Noguchi, H. \& Tilden, E. B. (1926). J. exp. Med. 44, 307.

Quastel, J. H. \& Wheatley, A. H. M. (1938). Biochem. J. 32 , 936.

Rapoport, S. (1937). Biochem. Z. 289, 406.

Reiner, L., Smythe, C. V. \& Pedlow, J. T. (1936). J. biol. Chem. 113, 75.

Robbie, W. A. (1946). J. cell. comp. Physiol. 27, 181.

Roe, J. H. (1934). J. biol. Chem. 107, 15.

Ryley, J. F. (1951). Biochem. J. 49, 577.

Ryley, J. F. (1952). Biochem. J. 52, 483.

Ryley, J. F. (1955). Biochem. J. 59, 361.

Somogyi, M. (1945). J. biol. Chem. 160, 61.

Warburg, O. \& Christian, W. (1943). Biochem. Z. 314, 149.

\title{
Studies on the Metabolism of the Protozoa
}

\section{METABOLISM OF THE PARASITIC FLAGELLATE TRICHOMONAS FOETUS*}

\author{
By J. F. RYLEY \\ Imperial Chemical (Pharmaceuticals) Limited, Biological Laboratories, Morley, Wilmslow, Cheshire
}

(Received 12 August 1954)

Trichomonas foetus is a flagellated protozoon parasitic in the reproductive tracts of bovines. It has a venereal transmission, and is one cause of abortion in cattle. It was first obtained in bacteriafree culture by Witte (1933), and since then numerous biochemical observations have been made on the flagellate in culture, but it was not until 1951 that Suzuoki \& Suzuoki (1951) carried out an investigation of the parasite in washed suspension. These workers studied particularly the metabolism of added glucose, and the sensitivity of this metabolism to inhibitors. They failed, however, to recognize the importance of the considerable intracellular glycogen reserves in the energy metabolism of the flagellate, and the relationship of this metabolism to that of extracellular substrates. In the present study, attention has been focused on the glycogen reserves of the parasite as the centre of its catabolic activities, and a number of enzyme systems have been demonstrated in cell-free preparations.

\section{MATERIAL AND METHODS}

Organisms. The Belfast strain of Trichomonas foetus, the McEntegart strain of $T$. vaginalis, and a strain of $T$. gallinae isolated in 1951 by $\mathrm{Dr}$ L. P. Joyner from a croplesion of a pigeon, were kindly supplied by my colleague $\mathrm{Mr}$ W. R. Jones. Stock cultures were maintained in the C.P.L.M. medium of Johnson \& Trussell (1943). For bulk growth, $T$. vaginalis was cultivated in McEntegart's (1952) medium containing $10 \%(v / v)$ horse serum, while $T$. foetus and $T$. gallinae were cultivated in a peptone-lemco medium which

\footnotetext{
* Part 4, Ryley (1955).
}

contained $1 \%(w / v)$ 'Oxoid' brand bacteriological peptone, $0.5 \%(w / v)$ 'Oxoid' Lab-lemco (Oxo Ltd.) and $0.5 \%(w / v)$ $\mathrm{NaCl}$. The $\mathrm{pH}$ was adjusted to $8 \cdot 4$, using phenolphthalein as indicator, and the medium was then boiled for $5 \mathrm{~min}$. to precipitate phosphates. After cooling, the solution was filtered, the $\mathrm{pH}$ adjusted to $7 \cdot 3$, and $0 \cdot 3 \%(\mathrm{w} / \mathrm{v})$ glucose added. The medium was autoclaved, and after cooling, $7 \%$ $(\mathrm{v} / \mathrm{v})$ sterile horse serum was added. Amounts (150 ml.) of this medium were inoculated with a tube of culture in C.P.L.M. medium, and after $48 \mathrm{hr}$. growth at $37^{\circ}$, half the culture was inoculated into a further 1.5 l. of the same medium. After $48 \mathrm{hr}$. growth, the organisms were harvested with a centrifuge, and washed and suspended in Ringerphosphate or Ringer-bicarbonate solutions as described by Ryley (1955).

Materials. The glycogen used in the investigations of intermediary metabolism was a purified specimen prepared from $T$. foetus (Manners \& Ryley, 1955). Adenosine triphosphate (ATP), cozymase and cytochrome $c$ were prepared as described by Ryley (1955), while Ca fructose 1:6diphosphate and $\mathrm{K}$ glucose 1-phosphate were obtained from L. Light and Co. Ltd.

Methods. The methods used were the same as those employed with Strigomonas oncopelti, (Ryley, 1955), except that all experiments were carried out at $37^{\circ}$. Metabolic rates were again based on nitrogen or dry-weight determinations. From a number of experiments, it was found that $1 \mathrm{mg}$. cellular $\mathrm{N}$ was equivalent to $0.95 \times 10^{8}$ flagellates, $10.3 \mathrm{mg}$. dry weight or about $64 \mathrm{mg}$. wet weight; these relationships are only approximate, due to the variable glycogen content of the organism; it should be noted that Suzuoki \& Suzuoki (1951) state that 'the dry weight of $10^{7}$ parasites was about $10 \mathrm{mg}$.', a relationship in error by a factor of ten. The present studies were carried out over the same period of time as those reported in the previous paper for S. oncopelti (Ryley, 1955); this gave a check on the methods employed, which in several cases gave negative results with $T$. foetus. 